\title{
Kim Göç Etmek İstiyor? Orta Doğu ve Kuzey Afrika'da Göç Eğilimleri
}

\author{
Yüksel Alper Ecevit* \\ Uğur Özdemir**
}

Öz

Orta Doğu ve Kuzey Afrika (MENA) ülkelerinde süregiden siyasi ve iktisadi istikrarsızlık, bölgede yaşayanların yeni bir yaşam arayışında olmasına yol açmakta ve bu arayış, göç etme isteğini de arttırmakta. Göç, MENA ülkelerinin tamamında kalıcı etkiler yaratacak bir olgu olarak önem arz ediyor. Kimlerin göç etmeyi tercih edeceği, hem geride bıraktıkları ülkelerdeki siyasal değişikliği şekillendirmekte, hem de yerleştikleri yeni ülkelerde sosyal hayata kalııı etkiler bırakmakta. Bu çalışmada, MENA bölgesinde yaşayan ve göç etme eğilimi gösteren bireylerin kararlarını şekillendiren sebepleri araştırdık. Göç etmeyi düşünenler ile düşünmeyenler arasındaki farkları değerlendirdik. Arap Barometresi oluşumunun 2016-2017 yılları arasında gerçekleştirdiği anket çalışmalarına dayanan ve 9 ülkede 7989 kişinin yanıtları ile toplanan verileri kullanarak gerçekleştirdiğimiz nicel analizde; eğitim düzeyi yüksek, siyasetten ve sosyal konulardan beklediğini bulamamış bireylerin göç etme eğiliminin daha yüksek olduğunu tespit ettik. Bu sonuçları değerlendirip olası sonuçlarını tartıştık.

Anahtar Kelimeler: Göç, MENA Bölgesi, Arap Barometresi.

\section{Who Wants to Emigrate? Contemporary Migration Trends in the MENA Region}

\section{Abstract}

Political and economic instabilities in the Middle East and North Africa (MENA) region instigate a pursuit of a new life among the populace which boosts the demand for migration. This is an important phenomenon which will have significant impacts on the MENA countries as well as the host countries. On the one hand, those who leave will trigger long-term societal and political changes in the destination countries, and on the other hand, those who stay will shape the future of their home countries. This study explores the individual level determinants of decision to emigrate from the MENA region. We investigated the differences between individuals who consider emigrating and those who prefer to stay. For this purpose, we used the Arab Barometer Wave IV data which was collected from 7989 individual respondents in nine countries. Our quantitative analysis indicate that those who are better educated, unsatisfied with politics and social life are more likely to emigrate from the region. We provide a discussion of these findings and their implications.

Keywords: Immigration, MENA Region, Arab Barometer.

* Dr. Öğr. Üyesi | Çukurova Üniversitesi | aecevit@cu.edu.tr | ORCID: 0000-0002-9267-0962

* Dr. Öğr. Üyesi | Edinburgh Üniversitesi | ugur.ozdemir@ed.ac.uk | ORCID: 0000-0001-6736-7008 Liberal Düşünce Dergisi, Yıl: 24, Sayı: 96, Güz 2019, ss. 9-25.

Gönderim Tarihi: 7 Eylül 2019 | Kabul Tarihi: 28 Kasım 2019

DOI: 10.36484/liberal.616815 


\section{Giriş}

Arap ülkelerinde siyasi ve ekonomik istikrarsızlık devam etmektedir. Bu istikrarsızlıklar, doğal olarak, Arap ülkelerinde yaşayan bireylerin yeni hayat arayışlarına girmesine yol açmaktadır. Bu süreçte, en yaygın davranışlardan biri de başka ülkelere göç ederek yeni hayatlar kurmak olarak öne çıkıyor. Birleşmiş Milletler Nüfus Birimi'nin 2017'de yayınladığı rakamlara göre tüm Kuzey Afrika ülkeleri, aldığı göçten daha fazlasını yurt dışına vermektedir. ${ }^{1}$ Örneğin, Fas, 2017 yılında göç ile aldığı sayıdan 250 bin fazlasını, Mısır ise 275 bin fazlasını ülkeden dışarıya göç olarak vermiştir. Bu rakamlar özellikle Arap Baharı sonrasındaki gelişmelerde hareketlilik kazanan göç olgusunun süreklilik kazandığını göstermektedir. Orta Doğu ve Kuzey Afrika'da bu tablo var iken, Türkiye sadece 2017 yılında ülke dişına verdiğinden 1.5 milyon fazla göçmeni ülkesine kabul etmiştir. Bu tablo göç alan ülkelerin bu akımların devam etme ihtimaline karşın göç süreçlerini planlama ve ihtiyaca göre politika yapımı konusundaki gerekliliği gözler önüne sermektedir.

Göç, sadece insan akışına dair rakamlardan ibaret bir husus olarak algılanmamalıdır. Göç sonucunda hareketlilik yaşayacak insanların hangi sebeplerle göç kararlarını aldıkları, sahip oldukları beşeri sermaye ve göç ettikleri yerlere dair beklentilerinin ne olduğu gibi hususlar, siyasi karar alıcılar için önem teşkil etmektedir. Ortadoğu ve Kuzey Afrika ülkelerinde (MENA Bölgesi) yaşayanların göç etme eğilimlerini ve bu eğilimlerin sebeplerini araştıracağız. Bu türden bir çalışma önümüzdeki dönemde yaşanabilecek göç dalgalarını anlamaya yarayacak ve bu göç dalgalarını makul düzeylerde tutabilmek ve yönetebilmek için gerekli yerel faktörleri de ortaya koyacaktır. Bu sebeple, araştırmamızın temel hedefi, MENA bölgesinde yaşayan insanların ne ölçekte hali hazırda göç etme düşüncelerinin olduğu ve bu eğilimin hangi gruplarda daha yaygın olduğunu sorgulamaktır.

Göç üzerine yapılan çalışmalarda göç etme kararının alımında 'iten ve çeken' faktörler (push and pull factors) olarak adlandırılan sebeplerin rol oynadığına vurgu yapılmaktadır. ${ }^{2}$ Bu anlamda 'iten faktörler' bir ülkeden insanların göç etmesine sebep olan ve o ülkeye özgü sebeplerdir. O ülkede yaşamayı zorlaştıran ekonomik, siyasal ve sosyal sorunların kişilerin bireysel olarak göç kararları üzerinde etkin olduğu düşüncesi 'iten faktörler' in nasıl işlevsel hale geldiğini açılklamaktadır. 'çeken faktörler’ ise göç eden bireylerin gidecekleri

1 UN DEPARTMENT OF SOCIAL AND ECONOMIC RELATIONS, International Migration Report (Uluslararası Göç Raporu), New York 2017. https://www.un.org/en/development/desa/population/ migration/publications/migrationreport/docs/MigrationReport2017_Highlights.pdf, (Erişim: 17 Ağustos 2019).

2 Everett S. Lee, “A Theory of Migration”, Demography, 1966, Sayı: 3, s. 47. 
ülkeleri seçerken kararlarında rol oynayan unsurlar ve gittikleri ülkelerde onlara cazip gelen şartlar olarak özetlenebilir. Biz bu çalışmada hedef ülkeleri neden tercih ettikleri sorusuna odaklanmayacağız. Çalışmanın odak noktası, göçmenlerin hangi sebeplerle ülkelerini terk ettiğini araştırmak ve dolayısıyla göç etme eğilimindeki kişilerin siyasi eğilimleri ve ekonomik durumları üzerine çıkarımlar yapmak olacaktır. Göç etme sebepleri ile ilgili akademik yazında var olan kaynaklara bakıldığında iktisadi ${ }^{3}$ ve siyasi ${ }^{4}$ koşulların yanı sıra kişilerin değer yargılarının ${ }^{5}$ da ön plana çıktığı görülmektedir. Bu nedenselliklerin MENA bölgesi için de açıklayıcı olup olmadığını gözlemlemek için bölgede gerçekleştirilmiş anket çalışmaları önemli kaynak oluşturmaktadır. Bu çalışmanın özgün değerini, MENA bölgesindeki göç etme eğiliminin bireysel düzeydeki değişkenlerle incelenmesi oluşturacaktır.

Araştırma sorusuna cevap vermek için Arap barometresi ${ }^{6}$ isimli çok say1da ülkenin içerildiği anket çalışmasının ürettiği veri seti kullanılacaktır. Arap barometresi, 2006 yılından bu yana MENA bölgesi olarak da bilinen 13 farklı Orta Doğu ve Kuzey Afrika ülkelerinde gerçekleştirilen temsili yüz-yüze anketlerle üretilen bir veri setidir. Kırsal ve kentsel nüfus ayrımını gözeterek gerçekleştirilmiştir. Bu ülkelerde düzenlenen ve kamuoyu anketleri arasında kullanıma açık en büyük veri kaynağıdır. 2006 yılından bu yana dört farklı anket dalgası halinde gerçekleştirilmiştir. Güncel olması nedeniyle bu çalışmada dördüncü dalgada toplanan veriler üzerine analiz gerçekleştirilecektir. Arap barometresi'nin dördüncü dalgası 2016-2017 yıllarında gerçekleştirilmiş ve bireylere siyasal, sosyal ve iktisadi konularda sorular yöneltilmiştir. Dördüncü dalga, dokuz farklı ülkede eş zamanlı gerçekleştirilen bir anket olması nedeniyle, daha önce belirttiğimiz araştırma sorusuna cevap vermemiz için en uygun kaynağı oluşturmaktadır. Bireysel düzeydeki eğilim ve tercih farklılıklarını anlamanın en doğal yöntemi anket çalışmalarına odaklanmaktır. Her ülkeden ortalama 1200 kişinin katıldığı yüz yüze görüşme ile gerçekleştirilen anketlerde artı eksi yüzde 3'lük bir güven aralığı oluşmuştur.

Anket, halen ülkesinde yaşayan bireyler üzerinde yapıldığından, göç etme kararını alıp uygulamış kişiler değil, hali hazırda ülkesinde yaşayan

3 Oded Stark ve J. Edward Taylor. "Relative Deprivation and International Migration”, Demography, 1989, Sayı: 26 (1), s. 2.

4 Dana M. Moss, Transnational Repression, "Diaspora Mobilization and the Case of the Arab Spring", Social Problems, 2016, Sayı: 63 (4), s. 480.

5 Chiara Falco ve Valentina Rotondi, "The Less Extreme, the More You Leave: Radical Islam and Willingness to Migrate”, World Development, 2016, Sayı: 88, ss. 130-132.

6 Arap Barometresi Dördüncü Dalga, https://www.Arabbarometer.org/survey-data/data-downloads/. (Erişim: 4 Temmuz 2019). 
bireyler üzerinde yapılmıştır. Dolayısıyla bireylerin göç kararını değil, göç etme eğilimini ölçmek üzerine araştırma olanağı tanımaktadır.

\section{MENA Ülkelerinde Göç Etme Eğilimini Belirleyen Faktörler}

Öncelikle MENA Bölgesi'ndeki göç eğilimlerine dair temel verileri incelemek yerinde olacaktır. Arap barometresi anketinde sorulan "Ülkenizden Göç Etmeyi Düşünüyor musunuz?" sorusu bu anlamda kişilere "Evet" ve "Hayır" olmak üzere iki cevap imkânı sunmuş ve göç eğilimi olan bireyleri değerlendirmemizi sağlamıştır. Bu soruya verilen cevaplardan oluşan veri, bu araştırmanın bağımlı değişkenini oluşturmuştur.

Arap Barometresi'nden Tablo 1'de görüldüğü gibi, 7 farklı ülkede 8989 kişiye yöneltilen 'Ülkenizden göç etmeyi düşünüyor musunuz?' sorusuna verilen cevaplara göre ankete katılanların yaklaşık yüzde 28'i yaşadıkları ülkeden göç etme isteklerini dile getirmişlerdir. Dünya Bankası'nın toplam nüfus verilerine göre 444 milyon kişinin yaşadığı MENA bölgesinde bu rakam yaklaşık 150 milyon kişinin muhtemelen ülke değiştirmeyi ve göç etmeyi düşündüğü anlamına gelmektedir.7 Bu rakamlardan yakın zamanda yeni göç dalgalarının oluşabileceği anlamı çıkarılabilir.

\begin{tabular}{|c|c|c|c|}
\hline \multicolumn{4}{|c|}{ Soru: Göç etmeyi düşünüyor musunuz? } \\
\hline Ülkeler & Evet & Hayır & Toplam (N) \\
\hline \multirow{2}{*}{ Cezayir } & 273 & 923 & \multirow{2}{*}{1196} \\
\hline & $22.8 \%$ & $77.2 \%$ & \\
\hline \multirow{2}{*}{ Misir } & 188 & 1012 & \multirow[t]{2}{*}{1200} \\
\hline & $15.7 \%$ & $84.3 \%$ & \\
\hline \multirow{2}{*}{ Ürdün } & 357 & 1143 & \multirow{2}{*}{1500} \\
\hline & $23.8 \%$ & $76.2 \%$ & \\
\hline \multirow{2}{*}{ Lübnan } & 498 & 999 & \multirow{2}{*}{1497} \\
\hline & $33.3 \%$ & $66.7 \%$ & \\
\hline \multirow{2}{*}{ Fas } & 331 & 866 & \multirow{2}{*}{1197} \\
\hline & $27.7 \%$ & $72.3 \%$ & \\
\hline \multirow{2}{*}{ Filistin } & 333 & 866 & \multirow{2}{*}{1199} \\
\hline & $27.8 \%$ & $72.2 \%$ & \\
\hline \multirow{2}{*}{ Tunus } & 269 & 931 & \multirow[t]{2}{*}{1200} \\
\hline & $22.4 \%$ & $77.6 \%$ & \\
\hline \multirow{2}{*}{ Tüm Ülkeler } & 2249 & 6740 & \multirow[t]{2}{*}{7989} \\
\hline & $28.15 \%$ & $71.85 \%$ & \\
\hline
\end{tabular}

7 Nüfus Verileri, Dünya Bankası, 2019. https://data.worldbank.org/indicator/SP.POP.TOTL?view=chart (Erişim: 17 Ağustos 2019). 
Göç etme eğilimi Lübnan'da nüfusun yüzde 33'ünde görülecek kadar yükselirken, en düşük göç etme eğiliminin yüzde 15.7 ile Mısır'da olduğu görülmüştür. Tunus gibi Arap Baharı'nın görece başarılı olduğu ve demokratik reformlar anlamında önemli ölçüde yol kat etmiş bir ülkede dahi yüzde 22.4'ün göç etme eğiliminde oluşu sorunun sadece siyasi olmadığı, daha karmaşık bir sebep-sonuç ilişkisi ile açıklanabileceğini göstermektedir. Hiç kuşkusuz ülkeler arasındaki farklar kadar bireylerin farklılıklarının göç eğilimlerine nasıl yansıdığı konusunda da ciddi bir araştırma sorusu ortaya çıkarmaktadır.

Çalışmanın geri kalan kısmında bireylerin göç etme kararını etkileyen faktörleri inceleyeceğiz. Bunun için bir dizi farklı değişkenin göç etme kararı üzerinde etkisi olup olmadığını, Pearson'ın ki-kare testini kullanarak test edeceğiz. Bu testin sonucunda ortaya çıkan 0.05 'ten daha küçük bir p-değeri, incelenen iki değişken arasında istatistiksel olarak anlamlı bir ilişki olduğu anlamını taşır.

Sırasıyla iktisadi, fiziksel ve kimlik değişkenlerine bakarak göç eğilimini şekillendiren etkenleri tespit edeceğiz.

\section{a. Iktisadi Şartlar}

Stark ve Taylor'ın göçün ekonomik etkenlerini açıkladığı çalışması göç çalışmalarında önemli bir alan açmıştır. ${ }^{8}$ Araştırmacılar, Meksika'nın kırsal kesiminde yaptığı çalışmalar sonucunda, çevresindeki diğer hanelere veya köylere göre yokluk yaşayan bireylerin göç kararlarını almakta olduklarını göstermişlerdir. Bu manada, yaşadığı bölgede işsizlik, yoksulluk veya gelir dağılımının adaletsizliğinden kurtulamayan bireyler göç ederek yeni hayatlar kurma kararı almaktadır. Bulunduğu yerde istediklerine ulaştığını düşünen ve sosyo-ekonomik koşullarını iyi yönde sağlamış bireylerin bulunduğu ülkede kalma olasılıkları artmaktadır.

8 Bkz. Dipnot 3. 


\begin{tabular}{|l|c|c|l|c|l|}
\hline Tablo 2: & \multicolumn{5}{|l|}{ İktisadi Şartlar ile Göç Etme Eğilimi Arasındaki İlişki } \\
\hline \multirow{2}{*}{$\begin{array}{l}\text { Soru: Göç } \\
\text { etmeyi } \\
\text { düşünüyor } \\
\text { musunuz? }\end{array}$} & \begin{tabular}{l} 
Soru: Hangi ibare sizin hanehalkı gelirini açılamaya daha yakın? \\
\cline { 2 - 6 } \\
yaşıtlıor ve \\
biriktiriyoruz
\end{tabular} & $\begin{array}{l}\text { Zorluk } \\
\text { çekmeden } \\
\text { yaşıyoruz }\end{array}$ & $\begin{array}{l}\text { Biraz } \\
\text { zorlukla } \\
\text { geçiniyoruz }\end{array}$ & $\begin{array}{l}\text { Ciddi } \\
\text { zorluklarla }\end{array}$ & Toplam \\
\hline Evet & 219 & 650 & 791 & 560 & 2220 \\
\hline & $22.6 \%$ & $23.1 \%$ & $25.1 \%$ & $28.5 \%$ & \\
\hline Hayır & 749 & 2165 & 2357 & 1407 & 6678 \\
\hline & $77.4 \%$ & $76.9 \%$ & $74.9 \%$ & $71.5 \%$ & \\
\hline Toplam & 968 & 2815 & 3148 & 1967 & 8898 \\
\hline & $10.9 \%$ & $31.6 \%$ & $35.4 \%$ & $22.1 \%$ & \\
\hline Ki-Kare & 21.06 & p-değeri= 0.0001 & & \\
\hline
\end{tabular}

Arap Barometresi'ne dayanan Tablo 2'deki verilere göre, rahat geçinen ailelerde göç etme oranı yüzde 22.6 iken, ciddi zorluklar yaşayan ailelerde yüzde 28.5'e kadar çıkmaktadır. Hanehalkı seviyelerine baktığımızda her yükselen kategoride, göç eğiliminin düştüğünü gözlemleyebiliyoruz. İki değişken arasındaki ilişki de istatistiksel olarak anlamlı çıkmaktadır. O halde, gelir durumu ile göç eğilimi arasında ters bir ilişki olduğu iddia edilebilir.

\begin{tabular}{|l|c|l|c|}
\hline Tablo 3: Eğitim ile Göç Etme Eğilimi Arasındaki İlişki \\
\hline $\begin{array}{l}\text { Soru: Göç etmeyi düşünü- } \\
\text { yor musunuz? }\end{array}$ & $\begin{array}{l}\text { Üniversite } \\
\text { Derecesi } \\
\text { Olmayanlar }\end{array}$ & $\begin{array}{l}\text { Üniversite } \\
\text { Mezunu ve Üzeri }\end{array}$ & Toplam \\
\hline Evet & 808 & 316 & 1124 \\
\hline & $21 \%$ & $33.5 \%$ & 3657 \\
\hline Hayır & 3031 & 626 & 4781 \\
\hline & $79 \%$ & $66.5 \%$ & \\
\hline Toplam & 3839 & 942 & $19.7 \%$ \\
\hline & $80.3 \%$ & p-değeri $=5.23 e-16$ & \\
\hline Ki-Kare & 65.70 & & \\
\hline
\end{tabular}

Göç eğilimini bu araştırma konusu olan ülkelerdeki gruplar üzerinde incelediğimizde üniversite eğitimine sahip bireylerin daha yüksek oranda ülkelerini terk etmek istediklerini görüyoruz. Arap barometresi anketine cevap verenlerin yaklaşık yüzde 20'si üniversite eğitimini tamamlamış bireylerden oluşuyor. Tablo 3’te ülkelerdeki verileri kıyasladığımız ‘Göç Etmeyi Düşünüyor Musunuz?’ anket sorusuna verilen cevapları eğitim seviyesine göre çapraz tablo ile ortaya koyduğumuzda üniversite eğitimi almış kişilerin istatistiksel 
olarak anlamlı bir ölçüde lise ve altı eğitimi almış kişilere oranla daha fazla göç etme eğiliminde olduğunu görüyoruz. Bu eğilimin sebepleri arasında, Kanada, Avustralya, ABD ve AB'nin yüksek eğitimli ve belli bir yetkinliğe sahip bireyleri almaktan yana göç politikalarının yer aldığını iddia etmek yanlış olmayacaktır. Ancak bu eğilim, MENA bölgesinden göç edecek kişilerin aynı zamanda bölge için ekonomik gelişim anlamında bir kayıp yaratabilecek ve 'beyin göçü' olarak algılanabilecek kişilerden oluştuğunu göstermektedir. Bu da uluslararası göçün hali hazırdaki durumu ile uyumlu görülebilir.?

Hükümetlerin önemli görevlerinden biri de toplumsal gelir adaletini sağlamak ve sosyal devlet ilkesinin gereklerini yerine getirerek toplumun dezavantajlı kesimlerinin de sağlıklı bir şekilde yaşamasını sağlamaktır. Buna bağlı olarak hükümetlerin gelir eşitsizliği konusunda önlemler alması da beklenir. Gelir eşitsizliğinin sağlanamadığı ve bağıl yoksunluk yaşayan bireyler daha sıklıkla göç etmeyi tercih etmektedir. ${ }^{10}$

\begin{tabular}{|c|c|c|c|c|c|}
\hline Tablo 4: & \multicolumn{5}{|c|}{$\begin{array}{l}\text { Hükümetin Ekonomik Politikaları ile Göç Etme Eğilimi } \\
\text { Arasındaki İlişki }\end{array}$} \\
\hline \multirow{2}{*}{$\begin{array}{l}\text { Soru: Göç et- } \\
\text { meyi düşünüyor } \\
\text { musunuz? }\end{array}$} & \multicolumn{5}{|c|}{$\begin{array}{l}\text { Soru: Hükümete zengin ile fakir arasındaki farkı azaltmas } \\
\text { konusunda ne kadar güveniyorsunuz? }\end{array}$} \\
\hline & Çok iyi & İyi & Kötü & $\begin{array}{r}\text { Çok } \\
\text { Kötü }\end{array}$ & Toplam \\
\hline \multirow[t]{2}{*}{ Evet } & 28 & 195 & 670 & 1039 & 1932 \\
\hline & & $15.6 \%$ & $22.5 \%$ & $29.3 \%$ & \\
\hline \multirow[t]{2}{*}{ Hayır } & 119 & 1054 & 2310 & 2512 & 5995 \\
\hline & $81.0 \%$ & $84.4 \%$ & $77.5 \%$ & $70.7 \%$ & \\
\hline \multirow[t]{2}{*}{ Toplam } & 147 & 1249 & 2980 & 3551 & 7927 \\
\hline & $1.9 \%$ & $26.2 \%$ & $37.6 \%$ & $44.8 \%$ & \\
\hline Ki-Kare & 106.04 & \multicolumn{3}{|c|}{ p-değeri < 2e-16 } & \\
\hline
\end{tabular}

Tablo 4'teki verilere göre hükümetin zengin ile fakir arasındaki eşitsizliği azaltamadığını düşünenler yüzde 82.4 iken, bu cevabı veren bireylerin daha sıklıkla göç etme eğiliminde olduğunu görebiliyoruz. Örneğin, hükümetin bu konuda çok kötü performans sağladığını düşünenlerin yüzde 29.3'ü gitme iradesini ortaya koyarken, hükümetin iktisadi olarak eşitlikçi toplum

9 Frederic Docquier ve Hillel Rapoport, “Globalization, Brain Drain and Development”, Journal of Economic Literature, 2012, Sayı: 50-3, ss. 681-684.

10 Oded Stark, “Inequality and Migration: A Behavioural Link”, Economic Letters, 2006, Sayı: 91(1), ss. 146-147. 
oluşturmadaki performansından çok memnun olanların yüzde 19'luk bir kısmı gitme iradesindedir. Bu bulgular ışığında kişilerin göç eğilimlerinde, içinde yaşadıkları durum kadar toplumun genelinde yaşananların ve hükümetin aldığı tedbirlerin de etkili olduğu söylenebilir.

\begin{tabular}{|c|c|c|c|c|c|}
\hline Tablo 5: & \multirow{2}{*}{\multicolumn{5}{|c|}{$\begin{array}{l}\text { İktisadi Adalet ile Göç Etme Eğilimi Arasındaki İlişki } \\
\text { Soru: Diğer vatandaşlara oranla size eşit davranıldığını dü- } \\
\text { şünüyor musunuz? }\end{array}$}} \\
\hline \multirow{2}{*}{$\begin{array}{l}\text { Soru: Göç } \\
\text { etmeyi düşünü- } \\
\text { yor musunuz? }\end{array}$} & & & & & \\
\hline & $\begin{array}{l}\text { Büyük } \\
\text { Oranda }\end{array}$ & $\begin{array}{l}\text { Yeterli } \\
\text { Oranda }\end{array}$ & $\begin{array}{l}\text { Sinırli } \\
\text { Oranda }\end{array}$ & $\begin{array}{l}\text { Hiç Eşit } \\
\text { Değiliz }\end{array}$ & Toplam \\
\hline \multirow[t]{2}{*}{ Evet } & 137 & 473 & 532 & 860 & 2002 \\
\hline & $14.1 \%$ & $17.4 \%$ & $28.3 \%$ & $32.5 \%$ & \\
\hline \multirow[t]{2}{*}{ Hayır } & 835 & 2241 & 1345 & 1784 & 6205 \\
\hline & $85.9 \%$ & $82.6 \%$ & $71.7 \%$ & $67.5 \%$ & \\
\hline \multirow[t]{2}{*}{ Toplam } & 972 & 2714 & 1877 & 2644 & 8207 \\
\hline & $11.8 \%$ & $33.4 \%$ & $22.9 \%$ & $32.2 \%$ & \\
\hline Ki-Kare & 237.99 & \multicolumn{3}{|c|}{ p-değeri <2e-16 } & \\
\hline
\end{tabular}

Tablo 5'teki bilgilere göre bireylerin yüzde 55.1'i eşit olmayan bir toplumda yaşadığını düşünmektedir. Kendisini diğer vatandaşlarla eşit görmeme hali, devletin kanun uygulamalarında bazı grup veya bireylere yönelik ayrıcalıklar yarattığı düşüncesi ile beraber oluşmaktadır. Buna bağlı olarak bireylerin, eşitsizlik yaratacak politikalara maruz bırakıldıklarında, göç ederek, kendilerini daha eşit hissedecekleri ülkelerde yaşamayı tercih etmeleri beklenebilir. Verilere baktığımızda, hiç eşit hissetmeyenlerin yüzde 32.5’i göç etme eğilimi gösterirken, büyük oranda eşit hissedenlerin sadece yüzde 14.1'i göç etme eğilimindedir. Sonuç olarak göç etme eğilimi ile eşit vatandaş hissetme arasında anlamlı bir ilişki söz konusudur. Toplumda eşitsizliğe uğradığını düşünen bireylerin göç etme eğilimleri daha fazladır.

\section{b. Fiziksel Şartlar ve Güvenlik}

Orta Doğu ve Kuzey Afrika ülkeleri siyasi istikrarsızlık ve dolayısıyla yaşanan karışıklıklar güvenlik sorununu da beraberinde getirmiştir. Suriye ve Libya'daki savaşlarda gördüğümüz üzere güvenlik sorunu nedeniyle ülkesini terk eden çok sayıda insan olduğu bilinmektedir. Arap barometresi'nde "kendinizin ve ailenizin güvenliğinin ne ölçüde sağlandığını düşünüyorsunuz?” şeklinde sorulan soruya bireylerin verdiği yanıtlarla göç eğilimleri arasındaki ilişkiyi incelediğimizde karşımıza Tablo 6'teki sonuçlar çıktı. 


\begin{tabular}{|c|c|c|c|c|c|}
\hline \multirow{3}{*}{$\begin{array}{l}\text { Soru: Göç } \\
\text { etmeyi düşünü- } \\
\text { yor musunuz? }\end{array}$} & \multicolumn{5}{|c|}{ Güvenlik ile Göç Etme Eğilimi Arasındaki İlişki } \\
\hline & \multicolumn{5}{|c|}{$\begin{array}{l}\text { Soru: Kişisel ve ailenizin güvenliğinin ne ölçüde sağlandığ } 1 \text { - } \\
\text { nı hissediyorsunuz? }\end{array}$} \\
\hline & $\begin{array}{l}\text { Tamamen } \\
\text { Güvenli }\end{array}$ & Güvenli & $\begin{array}{l}\text { Güvenli } \\
\text { Değil }\end{array}$ & $\begin{array}{l}\text { Kesinlikle } \\
\text { Güvenli } \\
\text { Değil }\end{array}$ & Toplam \\
\hline \multirow[t]{2}{*}{ Evet } & 429 & 891 & 611 & 310 & 2241 \\
\hline & $17.7 \%$ & $22.4 \%$ & $34.9 \%$ & $38.5 \%$ & \\
\hline \multirow[t]{2}{*}{ Hayır } & 1999 & 3095 & 1142 & 495 & 6731 \\
\hline & $82.3 \%$ & $77.6 \%$ & $65.1 \%$ & $61.5 \%$ & \\
\hline \multirow[t]{2}{*}{ Toplam } & 2428 & 3986 & 1753 & 805 & 8972 \\
\hline & $27.1 \%$ & $44.4 \%$ & $19.5 \%$ & $9.0 \%$ & \\
\hline Ki-Kare & 253.78 & \multicolumn{3}{|c|}{ p-değeri <2e-16 } & \\
\hline
\end{tabular}

Bu sonuçlara baktığımızda toplumun yaklaşık yüzde 72'si kendini ve ailesini güvende hissetmektedir. Ancak kesinlikle güvende hissetmeyen yüzde 9'luk grubun içinde yüzde 38.5'i göç etme eğiliminde iken, tamamen güvenli hisseden kitlenin içinde yaklaşık her 6 kişiden sadece biri göç etme eğilimi göstermektedir. Bu rakamlar ve ki-kare analizi, güvenlik sorunu yaşayanların göç etme eğiliminin arttığını göstermektedir.

\section{c. Dindarlık/Milliyetçilik}

Falco ve Rotondi (2016), bireylerin kararlarında radikal İslam'ın ne ölçüde ve nasıl etkili olduğunu araştırdıkları çalışmada, daha radikalleşmiş bireylerin göç etmekten yana olmadıklarını çünkü radikal değerlerin kişilerin göç kararları için daha yüksek oranda psikolojik yük ortaya çıkardıklarını ortaya koymaktaydı. ${ }^{11}$ Kendi ülkelerinde dindarlıkları üzerinden kurdukları arkadaşlıkların ve komşulukların gittikleri yerlerde olmayacağı kaygısıyla göç etmekten yana tavır almadıklarını iddia ediyorlar. Benzer bir çalışmayı ABD’nin Utah kentinde yaşayan Mormonlar üzerinde gerçekleştiren Stinner vd.'in (1992) araştırmasında kiliseye aktif olarak katılanların göç etme eğilimlerinin daha az olduğunu bulmuşlardı. ${ }^{12}$ Hoffman ve diğerleri de (2015) Meksika'da yaşayanlar üzerine yaptığı çalışmada dışa dönük dindarlıkları fazla olanların, bir başka deyişle dinini toplum ile birlikte yaşadığı pratiklerle uygulamaya dökenlerin daha az göç etme isteklerinin olduğunu, ancak kendi içinde dini değerlere daha

11 Bkz. Dipnot 5.

12 William F. Stinner, Mollie van Loon ve Yongchang Byun, "Plans to Migrate in and Out of Utah", Sociology and Social Research, 1992, Sayı: 76(3), ss. 131-133. 
bağlı olanların göç etmeyi tercih ettiklerini bulmuşlardı. ${ }^{13} \mathrm{Bu}$ durumda dindarlık, bu çalışmada da bağımsız değişkenlerden biri olarak tercih edilmiştir.

\begin{tabular}{|l|c|l|l|l|}
\hline \multirow{2}{*}{ Tablo 7: } & \multicolumn{4}{|c|}{ Dindarlık ile Göç Etme Eğilimi Arasındaki İlişki } \\
\hline \multirow{2}{*}{$\begin{array}{l}\text { Soru: Göç etmeyi } \\
\text { düşünüyor musunuz? }\end{array}$} & \multicolumn{4}{|l|}{ Soru: Genel olarak kendinizi nasıl tarif edersiniz? } \\
\cline { 2 - 5 } & Dindar & $\begin{array}{l}\text { Az Çok } \\
\text { Dindar }\end{array}$ & $\begin{array}{l}\text { Dindar } \\
\text { Değil }\end{array}$ & Toplam \\
\hline Evet & 557 & 1268 & 403 & 2220 \\
\hline & $17.6 \%$ & $26.2 \%$ & $43.0 \%$ & \\
\hline Hayır & 2603 & 3575 & 535 & 6713 \\
\hline & $82.4 \%$ & $73.8 \%$ & $57.0 \%$ & \\
\hline Toplam & 3160 & 4843 & 938 & 8941 \\
\hline & $35.3 \%$ & $54.2 \%$ & $10.5 \%$ & \\
\hline Ki-Kare & 257.19 & \multicolumn{4}{|c|}{ p-değeri <2e-16 } & \\
\hline
\end{tabular}

Tablo 7'de özetlediğimiz sonuçlara göre, MENA bölgesindeki bireylerde dindarlığın göç etme kararında önemli bir etken olduğunu görebiliyoruz. 'Kendinizi nasıl tarif edersiniz?' şeklinde sorulan soruya bağlı olarak bireyler kendilerini konumlandırdıklarında, kendisini dindar olarak tarif edenlerin sadece yüzde 17.6'sı göç etme eğilimi gösterirken, dindar olmadığını ifade edenlerin yüzde 43’ü göç etme eğilimi göstermektedir. Bu bağlamda, MENA bölgesi bulguları, göç literatürü beklentileri ile örtüşmektedir.

\section{d. Siyasi Gelişmeler}

\begin{tabular}{|l|c|c|c|c|c|}
\hline Tablo 8: & \multicolumn{6}{|l|}{ Siyasete Olan ilgi ile Göç Etme Eğilimi Arasındaki İlişki } \\
\hline \multirow{2}{*}{$\begin{array}{l}\text { Soru: Göç etmeyi } \\
\text { düşünüyor } \\
\text { musunuz? }\end{array}$} & \multicolumn{2}{|c|}{ Soru: Siyaset ile ne kadar ilgilisiniz? } \\
\cline { 2 - 6 } & $\begin{array}{l}\text { Çok } \\
\text { ilgiliyim }\end{array}$ & İlgiliyim & $\begin{array}{l}\text { Biraz } \\
\text { İlgiliyim }\end{array}$ & $\begin{array}{l}\text { Hiç ilgili } \\
\text { Değilim }\end{array}$ & Toplam \\
\hline Evet & 185 & 386 & 723 & 953 & 2247 \\
\hline & $23.8 \%$ & $23.8 \%$ & $25.7 \%$ & $25.5 \%$ & \\
\hline Hayır & 593 & 1237 & 2095 & 2789 & 6714 \\
\hline & $76.2 \%$ & $76.2 \%$ & $74.3 \%$ & $74.5 \%$ & \\
\hline Toplam & 778 & 1623 & 2818 & 3743 & 8961 \\
\hline & $8.7 \%$ & $18.1 \%$ & $31.4 \%$ & $41.8 \%$ & \\
\hline Ki-Kare & 2.95 & \multicolumn{7}{|c|}{ p-değeri=0.399 } & \\
\hline
\end{tabular}

13 Steven Hoffman, Flavio Francisco Marsiglia ve Stephanie L. Ayers, "Religiosity and Migration Aspirations Among Mexican Youth”, Journal of International Migration and Integration, 2015, Sayı: 16, ss. 173-174. 
Kişilerin göç kararlarını alırken siyaset ile olan ilişkisi de önemli yer teşkil etmektedir. Siyasete karşı ilgisi çok olan bireyler, eğer siyasal süreçlerin beklentilerine karşılık veremediklerini düşünüyorlarsa sosyal ve ekonomik haklarını daha iyi koruyabildikleri yere gitmeyi tercih edebilirler. Bu anlamda siyasete olan ilgilerine göre bireylerin göç etme eğilimleri tablosu bize önemli bir ipucu vermektedir. Arap barometresi anketinin içerisine dahil edilen 'Siyaset ile ne derece ilgilisiniz?' sorusu ile 'Ülkenizi terk etmeyi düşünüyor musunuz?’ sorusuna verilen cevapları çapraz tablolama ile gösterdiğimizde ilginç sonuçlara ulaşmaktayız. Siyasetle ilgilenme oranları ile kişilerin göç etme eğilimleri arasında bir ilişkinin var olmadığı hipotezini reddedememekteyiz, yani bu iki değişken arasında anlamlı bir ilişkinin olduğunu gösterememekteyiz. Çok ilgili, ilgili, biraz ilgili ve hiç ilgili olmayan şeklinde ayrılan tüm kategorilerde yaklaşık 4 kişiden 3'ü ülkesinde kalmayı, diğeri ise ülkesini terk etmeyi düşünmektedir. Siyaseti çok takip ediyor olması, bireylerin ülkelerini terk etmeleri hususunda rol oynamamaktadır. Bir başka deyişle kişilerin siyasal sosyalleşmesi ile göç etmesi arasındaki ilişkiye dair bir bulgu bulunmamaktadır. Ancak bu siyasi süreçlerle göç etme eğilimi arasında ilişki olmadığı anlamına gelmemektedir. Çünkü siyasete karşı ilgi, siyasal süreçlere katılımın sadece bir ayağını oluşturmaktadır. Diğer katılım süreçlerine baktığımızda bazı farklılıklar gözükmektedir.

\begin{tabular}{|l|c|c|c|}
\hline \multicolumn{4}{|l|}{ Tablo 9: Oy Verme Davranışı ile Göç Etme Eğilimi Arasındaki İlişki } \\
\hline $\begin{array}{l}\text { Soru: Göç etmeyi } \\
\text { düşünüyor musunuz? }\end{array}$ & Oy verenler & Oy vermeyenler & \\
\hline Evet & 744 & 1276 & 2020 \\
\hline & $17.7 \%$ & $30.6 \%$ & \\
\hline Hayır & 3453 & 2891 & 6344 \\
\hline & $82.3 \%$ & $69.4 \%$ & \\
\hline Toplam & 4197 & 4167 & 8364 \\
\hline & $50.2 \%$ & $49.8 \%$ & \\
\hline Ki-Kare & 189.792 & p-değeri <2e-16 & \\
\hline
\end{tabular}

Göç eğiliminin siyasi gelişmeler ile birbirine bağlı olduğunu rahatlıkla söyleyebiliriz. Bir ülkedeki kurumsallaşmış adaletsizlik, iç savaş veya siyasi istikrarsızlık kişilerin iyiye doğru gidiş konusunda ümitlerini azaltmaktadır. Ülke içinde anayasa çerçevesinde kabul görmüş siyasi karar alma kanallarının beklenen sonucu veremeyecek gibi algılanması bireylerin arayışlarını ülke dışına yöneltmesine yol açmaktadır. Hatta bazı gruplar diaspora olarak siyasette aktif olmayı ülke içinde muhalefet etmeye göre daha etkin 
görmektedir. ${ }^{14}$ O yüzden, siyasi kanalların farklı gruplara açık olması çok önemlidir. Hiç kuşkusuz işleyen bir demokrasi ve rekabetçi seçim unsurları, bireylerde değişimin mümkün olduğuna dair bir umut yaratmaktadır.

Arap Barometresi’nin yönelttiği sorulardan biri, oy verme davranışıyla göç etme istekleri arasındaki ilişkiyi inceleme fırsatı vermektedir. Tablo 9'da görüldüğü üzere, son genel seçimde oy kullananların yüzde 17.7'si göç etmek isterken, bu rakam oy vermeyenler arasında yüzde 30'un üzerine çıkmaktadır. Kısaca ifade edersek, göç etme isteği, oy kullanmayanlar arasında belirgin biçimde daha yüksek çıkmaktadır. Bu durumu, göç etmek isteyenlerin siyasi katılımın en önemli bileşeni olan oy verme davranışından vazgeçtikleri şeklinde yorumlamak mümkün. Bir başka deyişle, göç etmek isteyenlerin, ülkelerinde yaşanan demokratik süreçlerle daha iyiye doğru gidebileceğinden umudunu kesmiş olduğunu söyleyebiliriz.

\begin{tabular}{|l|l|l|c|}
\hline \multicolumn{4}{|c|}{ Tablo 10: Gösterilere katılım ile Göç Etme Eğilimi Arasındaki İlişki } \\
\hline $\begin{array}{l}\text { Soru: Göç etmeyi } \\
\text { düşünüyor musunuz? }\end{array}$ & $\begin{array}{l}\text { Gösteriye } \\
\text { Katılanlar }\end{array}$ & $\begin{array}{l}\text { Gösteriye } \\
\text { Katılmayanlar }\end{array}$ & Toplam \\
\hline Evet & 339 & 1672 & 2011 \\
\hline & $26.9 \%$ & $23.6 \%$ & \\
\hline Hayır & 920 & 5408 & 6328 \\
\hline & $73.1 \%$ & $76.4 \%$ & 8339 \\
\hline Toplam & 1259 & 7080 & \\
\hline & $15.1 \%$ & $84.9 \%$ & \\
\hline Ki-Kare & 6.40 & p-değeri=0.0114 & \\
\hline
\end{tabular}

Siyasi katılımın bir başka yöntemi olan gösterilere katılmak üzerine ankette sorulan soruya verilen cevaplara baktığımızda da gösteriye katılma ile göç etme eğilimi arasında anlamlı bir bağlantı göremiyoruz. Gösterilere katılanlar ortalama olarak biraz daha fazla göç eğiliminde olsalar da aralarındaki farklılık istatistiksel olarak anlamlı farklılık olarak gözükmüyor. Dolayısıyla ülkedeki sorunlara karşı gösterilere katılarak görüş bildirmeyen bireylerin bir kısmı yurtdışına gitmek isterken gösterilerin siyasi olaylara karşı bir tepki olduğunu söyleyebiliriz. Fakat gösterilere katılmayanlar arasında yüzde 23'lük bir kitlenin göç etme eğiliminde olması, kişilerin siyasi olaylara karşı tepkisiz kalırken dahi göç etme eğilimlerini koruyabildikleri konusunda dikkat çekicidir.

14 Bkz. Dipnot 4. 


\begin{tabular}{|l|c|c|c|}
\hline \multicolumn{4}{|c|}{ Tablo 11: Genelleştirilmiş Güven ile Göç Etme Eğilimi Arasındaki İlişki } \\
\hline & Soru: Sizce insanların çoğuna güvenilir mi? \\
\hline $\begin{array}{l}\text { Soru: Göç etmeyi } \\
\text { düşünüyor musunuz? }\end{array}$ & Evet & Hayır & Toplam \\
\hline Evet & 315 & 1908 & 2223 \\
\hline & $19.4 \%$ & $26.2 \%$ & \\
\hline Hayır & 1308 & 5387 & 6695 \\
\hline & $80.6 \%$ & $73.8 \%$ & \\
\hline Toplam & 1623 & 7295 & 8918 \\
\hline & $18.2 \%$ & $81.8 \%$ & \\
\hline Ki-Kare & 32.29 & p-değeri=1.33e-08 & \\
\hline
\end{tabular}

MENA bölgesi, genel olarak insanların 'Genelleştirilmiş Güven' olarak tabir edilen kişilerarası güven konusunda geride olduğunu göstermektedir. Arap barometresi’nin dördüncü dalgası sonuçlarına göre bu bölgede yaşayan insanların sadece yüzde 18.2'i toplumdaki insanların çoğunun güvenilir olduğuna inanmaktadır. Literatüre baktığımız zaman sosyal sermayenin bir parçası olarak gösterilen bu değişkenin düşük olduğu ülkelerde siyasal mekanizmaların ve özellikle demokratik kurumların da işleyişinde sorunlar olduğu gözükmektedir. ${ }^{15}$ Genel olarak konuşmak gerekirse, sizce insanların çoğu güvenilir midir?' sorusuna verilen yanıtları göç etme eğilimi ile karşılıklı tabloladığımız zaman ise göç etme eğiliminde olan kişiler arasında genelleştirilmiş güvenin de az olduğu göze çarpmaktadır. Gitme eğilimindeki bireylerin arasında insanların güvenilir olmadığını düşünenlerin sayısı anlamlı bir şekilde daha fazladır. Kalma eğiliminde olanların ise daha sıklıkla insanları güvenilir bulduğunu görüyoruz. Sosyal güveni fazla olan bireylerin hayattan memnuniyetleri ve iyimserlikleri de fazla olduğundan, göç etme eğilimlerinin de düşüyor olması beklenen bir sonuçtur. ${ }^{16}$ Yukarıdaki tablo göstermektedir ki, literatürün oluşturduğu beklenti Arap ülkeleri için de geçerlidir.

Genelleştirilmiş güven gibi bir başka önemli sosyal sermaye unsuru da bireylerin toplumsal liderlere ve kurumlara duyduğu güvenin göç eğilimleri üzerine etkili olabileceğini söyleyebiliriz. Buna göre belli siyasi veya toplumsal figürlere güven duyan, bu liderlerin ülkenin geleceğini iyi yönde

15 Stephen Knack, "Social Capital, Growth and Poverty: A Survey of Cross-Country Evidence”, The Role of Social Capital in Development: An Empirical Assessment, 2002, ss. 42-43. Margit Tavits, "Making Democracy Work More? Exploring The Linkage Between Social Capital and Government Performance", Political Research Quarterly, 2006, ss. 211-213.

16 John F. Helliwell, “How's Life? Combining Individual and National Variables To Explain Subjective Well-being", Economic Modelling, Sayı: 20(2), ss. 331-332. Eric Uslaner, The Moral Foundations of Trust, Cambridge University Press, Cambridge 2002. 
şekillendireceğine inanan bireylerin göç etmek yerine ülkesinde kalmayı tercih edeceği düşünülebilir. MENA bölgesinde din faktörünün toplumsal hayatı şekillenmede önemli bir rol oynadığını da düşünürsek, dini liderlere olan güvenin etkili olabileceğini bekleriz.

\begin{tabular}{|c|c|c|c|c|c|}
\hline \multirow{3}{*}{$\begin{array}{l}\text { Tablo 12: } \\
\text { Soru: Göç et- } \\
\text { meyi düşünü- } \\
\text { yor musunuz? }\end{array}$} & \multicolumn{5}{|c|}{ Kişilere olan Güven ile Göç Etme Eğilimi Arasındaki İlişki } \\
\hline & \multicolumn{5}{|c|}{ Dini liderlere ne kadar güveniyorsunuz? } \\
\hline & Çok & Güveniyorum & Biraz & Hiç & Toplam \\
\hline \multirow[t]{2}{*}{ Evet } & 228 & 487 & 537 & 709 & 1961 \\
\hline & $17.0 \%$ & $21.0 \%$ & $24.4 \%$ & $32.3 \%$ & \\
\hline \multirow[t]{2}{*}{ Hayır } & 1115 & 1831 & 1663 & 1486 & 6095 \\
\hline & $83.0 \%$ & $79.0 \%$ & $75.6 \%$ & $67.7 \%$ & \\
\hline \multirow[t]{2}{*}{ Toplam } & 1343 & 2318 & 2200 & 2195 & 8056 \\
\hline & $16.7 \%$ & $28.8 \%$ & $27.3 \%$ & $27.2 \%$ & \\
\hline Ki-Kare & 129.03 & \multicolumn{3}{|l|}{ p-değeri <2e-16 } & \\
\hline
\end{tabular}

Tablo 12'de görünen o ki, her ne kadar din adamlarına güven arttıkça göç eğilimi azalıyor gibi görünse de Ki-Kare testi sonuçları iki değişkenin birbirinden bağımsız olduğunu reddediyor. Dolayısıyla bireylerin göç kararları din adamlarına olan güvenle de ilişkili bir şekilde oluşmakta. Toplumsal aktörlere güven problemi yaşayanların göç etmeye eğilimli oldukları ortaya çıkmaktadır. Bu bağlamda, gözlenen durumun sadece din adamları için mi geçerli olduğu; seküler siyasetin parçası olan kurumlar için de geçerli olup olmadığı sorusuna da yanıt aramak gerekiyor.

\begin{tabular}{|c|c|c|c|c|l|}
\hline Tablo 13: & \multicolumn{6}{|l|}{ Kurumlara olan Güven ile Göç Etme Eğilimi Arasındaki İlişki } \\
\hline \multirow{2}{*}{$\begin{array}{l}\text { Soru: Göç et- } \\
\text { meyi düşünü- } \\
\text { yor musunuz? }\end{array}$} & Orduya ne kadar güveniyorsunuz? & Güveniyorum & Biraz & Hiç & Toplam \\
\cline { 2 - 6 } Evet & 1031 & 475 & 256 & 236 & 1998 \\
\hline & $20.8 \%$ & $26.2 \%$ & $29.7 \%$ & $37.5 \%$ & \\
\hline Hayır & 3925 & 1336 & 606 & 394 & 6261 \\
\hline & $79.2 \%$ & $73.8 \%$ & $70.3 \%$ & $62.5 \%$ & \\
\hline Toplam & 4956 & 1811 & 862 & 630 & 8259 \\
\hline & $60.0 \%$ & $21.9 \%$ & $10.4 \%$ & $7.6 \%$ & \\
\hline Ki-Kare & 109.86 & p-değeri <2e-16 & & \\
\hline
\end{tabular}

Tablo 13'e baktığımızda askere olan güvenin göç kararı üzerinde etkili olup olmadığını gözlemleyebiliyoruz. Tabloya baktığımızda askeri kurumlara güven duyan bireylerin daha düşük bir oranla göç etmekten yana tavır aldığını 
görüyoruz. Orduya çok güvenenler arasında yüzde 79 ülkeden göç etmemekten yana tavır ortaya koyarken, hiç güvenmeyenlerin yüzde 62.5’i ülkede kalmayı tercih etmektedir. Bu durumda orduyu, devletin bir kurumu olarak gördüklerini ve buna bağlı olarak devlet kurumlarına olan güven arttıkça göç eğiliminin azaldığını görüyoruz.

\begin{tabular}{|c|c|c|c|c|c|}
\hline \multirow{3}{*}{$\begin{array}{l}\text { Tablo 14: } \\
\text { Soru: Göç } \\
\text { etmeyi düşünü- } \\
\text { yor musunuz? }\end{array}$} & \multicolumn{5}{|c|}{ Kurumlara olan Güven ile Göç Etme Eğilimi Arasındaki İlişki } \\
\hline & \multicolumn{5}{|c|}{ Yargıya ne kadar güveniyorsunuz? } \\
\hline & Çok & Güveniyorum & Biraz & Hiç & Toplam \\
\hline \multirow[t]{2}{*}{ Evet } & 222 & 449 & 540 & 772 & 1983 \\
\hline & $16.0 \%$ & $19.2 \%$ & $25.5 \%$ & $34.1 \%$ & \\
\hline \multirow[t]{2}{*}{ Hayır } & 1164 & 1895 & 1578 & 1490 & 6127 \\
\hline & $84.0 \%$ & $80.8 \%$ & $74.5 \%$ & $65.9 \%$ & \\
\hline \multirow[t]{2}{*}{ Toplam } & 1386 & 2344 & 2118 & 2262 & 8110 \\
\hline & $17.1 \%$ & $28.9 \%$ & $26.1 \%$ & $27.9 \%$ & \\
\hline Ki-Kare & 204.89 & \multicolumn{3}{|c|}{ p-değeri <2e-16 } & \\
\hline
\end{tabular}

Bireylerin bir sisteme bağlılık hissetmelerinin önemli koşullarından biri adaletli bir sosyal yapı içinde olduklarını düşünmelidir. Yargı sistemi de toplumsal adaleti sağlayan en önemli devlet mekanizmasıdır. Dolayısıyla yargıya güvenen bireylerin yaşadıkları topluma bağlı kalması beklenir. Adaletsiz bir toplumda yaşadığını düşünenlerin ise göç etme eğiliminin artması beklenmektedir. Tablo 14'te gördüğümüz üzere yargıya çok güvenenlerin yüzde 84 oranında kalma eğiliminde olduğu ortaya çıkarken, hiç güvenmeyenlerin yüzde 34.1 oranında göç etme eğiliminde olduğunu görüyoruz. Bu tablo, bireylerin devletten beklentilerinin karşılanmadığı durumlarda ülkeyi terk etme eğiliminde olduğunu göstermektedir.

\begin{tabular}{|l|c|c|c|c|c|}
\hline Tablo 15: & \multicolumn{5}{|l|}{ Kurumlara olan Güven ile Göç Etme Eğilimi Arasındaki İlişki } \\
\hline $\begin{array}{c}\text { Soru: Göç } \\
\text { etmeyi düşünü- } \\
\text { yor musunuz? }\end{array}$ & Hükümete ne kadar güveniyorsunuz? \\
\cline { 2 - 6 } & Çok & Güveniyorum & Biraz & Hiç & Toplam \\
\hline Evet & 139 & 344 & 521 & 999 & 2003 \\
\hline & $13.2 \%$ & $15.9 \%$ & $25.4 \%$ & $33.6 \%$ & \\
\hline Hayır & 913 & 1816 & 1527 & 1977 & 6233 \\
\hline & $86.8 \%$ & $84.1 \%$ & $74.6 \%$ & $66.4 \%$ & \\
\hline Toplam & 1052 & 2160 & 2048 & 2976 & 8236 \\
\hline & $12.8 \%$ & $26.2 \%$ & $24.9 \%$ & $36.1 \%$ & \\
\hline Ki-Kare & 292.9 & p-değeri <2e-16 & & \\
\hline
\end{tabular}


Devlet kurumlarının bir temel unsurlarından yürütme erkinin başı konumundaki hükümetin de politikaları ve sorunlara yaklaşımı bireylerin sisteme olan güven duygusunu ve ülkede yaşam kurma eğilimini şekillendirmektedir. Tablo 14 'te görüldüğü gibi hükümete duyulan güven MENA bölgesindeki bireylerin göç etme eğilimleri üzerinde de etkili gözükmektedir. Hükümete çok güvenen bireylerin yüzde 13.2'si gitme eğiliminde iken hiç güvenmeyenlerde bu oran yüzde 33.6'ya çıkmaktadır. Her ne kadar hükümetler sistemin geçici bir unsuru olarak gözükse de MENA bölgesinde uzun süreli otoriter hükümetlerin halkın ülkede yaşama duygusunu derinden etkilediği gözükmektedir. Bireylerin güvenini kazanabilecek hükümetler ülke içerisinde yaşama iradelerini de arttırabilir gözükmektedir.

\section{Sonuç}

Göç dalgalarının hem iç siyaseti hem de uluslararası ilişkileri şekillendirdiği günlerde, siyasal ve iktisadi açıdan en istikrarsız bölgelerin başında gelen MENA bölgesindeki bireylerin göç eğilimlerini inceleyerek yakın zamanda oluşabilecek muhtemel dalgaları anlamaya çalıştık.

$\mathrm{Bu}$ araştırma bulgularının iki önemli sonucu ortaya çıkmaktadır. Birincisi, MENA bölgesinden eğitimli ve beşeri sermayesi yüksek bir kitle daha adil ve demokratik kurumlarına güven duyabileceği bölgelere tercih ediyor. Avrupa Birliği, Kanada ve Avustralya gibi ülkelerin özellikle nitelikli göçmene uyguladığı açık politikalar düşünülünce yakın dönemde bu bölgelere göç akımları görebiliriz. Dolayısıyla MENA bölgesinden göç edecek beşeri sermayesi yüksek bireylerin yeni vatanlarına değer katma ihtimali yüksek görünmektedir. Savaş durumlarında kitle göçü gerçekleşirken göçmenlerin gittikleri topluma katkısı tartışılırken, nitelikli göçmen özellikle sanayi toplumlarında ve gelişmekte olan ülkelerde her zaman cazip gözüküyor.

İkinci önemli sonuç ise, MENA ülkeleri modernleşme ve demokratikleşme süreçlerini henüz tamamlamamışken modern kurumlara inanan, nasıl çalıştığını bilen, ancak sonuçlarından memnun olmayan eğitimli bir kesimin ülkeyi terk etme isteği ve bu kitlenin siyasi katılımdan da imtina ediyor olması MENA ülkelerinin önümüzdeki süreçte siyasi istikrarı yakalamasını zorlaştıracak gibi gözüküyor.

MENA ülkelerinin iç siyasette özellikle kurumsal gelişimi destekleyecek hamleleri kuvvetlendirmesi, hükümetlerin politikalarında herhangi bir grubu göz ardı etmemesi ve adil davranması gerekirken, gelir dağılımı konusunda önlemler alması gerekmektedir. MENA bölgesinden oluşacak göçlerin 
önemli hedef ülkelerinden biri olabilecek Türkiye'nin ise bu bireyler içerisinde ülkenin kalkınmasına katkıda bulunacak bireylere cazip imkânlar sunması ve bölgedeki yumuşak gücünü arttırıcı nitelikte eylemlerde bulunması önem arz etmektedir.

\section{Kaynakça}

DOCQUIER, Frederic ve RAPOPORT, Hillel, “Globalization, Brain Drain, and Development", Journal of Economic Literature, 2012, Sayı:50 (3), ss. 681-730.

FALCO, Chiara ve ROTONDI, Valentina, "The Less Extreme, the More You Leave: Radical Islam and Willingness to Migrate", World Development, 2016, Sayl: 88, ss. 122-133.

HELLIWELL, John F, "How's life? Combining Individual and National Variables To Explain Subjective Well-being”, Economic modelling, 2003, Sayı: 20 (2), ss. 331-360.

HOFFMAN, Steven, MARSIGLIA, Flavio Francisco ve AYERS, Stephanie L., "Religiosity and Migration Aspirations Among Mexican Youth", Journal of International Migration and Integration, 2015, Sayı:16, ss. 173-186.

KNACK, Stephen, "Social Capital, Growth and Poverty: A Survey of Cross-Country Evidence," Ed. C. Grootaert \& T. van Bastelaer, The Role of Social Capital in Development: An Empirical Assessment, 2002, Cambridge: Cambridge University Press, ss. 42-82.

LEE, Everett S., “A Theory of Migration”, Demography, 1966, Sayl: 3, ss. 47-57.

MOSS, Dana M, "Transnational Repression, Diaspora Mobilization and the Case of the Arab Spring", Social Problems, 2016, Sayı: 63(4), ss. 480-498.

STARK, Oded, ve TAYLOR, J. Edward, "Relative Deprivation and International Migration", Demography, 1989, Sayı: 26 (1), s. 2.

STARK, Oded, "Inequality and Migration: A Behavioural Link", Economic Letters, 2006, Sayı: 91(1), ss. 146-152.

STINNER, William F., VAN LOON, Mollie ve BYUN, Yongchang, "Plans to Migrate in and Out of Utah", Sociology and Social Research, 1992, Sayı: 76(3), ss. 131-137.

TAVITS, Margit, "Making Democracy Work More? Exploring The Linkage Between Social Capital And Government Performance", Political Research Quarterly, 2006, Sayl: 59(2), ss. 211-225.

UN DEPARTMENT OF SOCIAL AND ECONOMIC RELATIONS, International Migration Report, New York 2017.

USLANER, Eric, The Moral Foundations of Trust, Cambridge University Press, Cambridge 2012. 